\title{
RAFTING SCREWS VERSUS BONE GRAFTS IN DEPRESSED TIBIAL PLATEAU FRACTURES
}

\author{
By \\ Muhammad Ahmed Abd El-Samad, Ali Al-Gioushy and Ehab El-Zahed \\ Department of Orthopedic Surgery, Faculty of Medicine, Al-Azhar University \\ Corresponding author: Muhammad Ahmed Abd El-Samad, \\ E-mail: m2a.sabawy@gmail.com
}

\begin{abstract}
Background: Tibial plateau fractures involve a major weight-bearing joint. They occur due to a combination of axial loading and varus/valgus applied forces leading to articular depression, malalignment and an increased risk of post-traumatic osteoarthritis.

Objective: To evaluate the clinical, radiographic and functional results in a cohort of patients who sustained open reduction and internal fixation by rafting screws $3.5-6.5 \mathrm{~mm}$ cortical screws.

Patients and methods: A total number of 30 cases were included in this study and divided into 2 equel groups: Group (A) and group (B). The demographic data showed sex distribution as 22 males \& 8 females with closed lateral tibial plateau fractures (18 type II \& 12 type III). As regard to radiological outcome, there was no significant difference between both groups during the period between December 2019 and November 2020 at Al-Hussein University Hospital.
\end{abstract}

Results: Functional and radiological results without using graft were slightly lesser than when graft was used, but it avoided possible donor site complications of the graft, decreased blood loss and minimized operative time.

Conclusion: Treating depressed tibial plateau fractures type II and type III with mild or moderate depression $(<1.5 \mathrm{~cm})$ by open reduction and internal fixation using large set buttress plate and screws or screws alone without using bone graft or bone graft substitute represented a viable option.

Keywords: Rafting screws, Bone grafts, Tibial plateau fractures.

\section{INTRODUCTION}

Tibial plateau fractures involve a major weight-bearing joint. They occur due to a combination of axial loading and varus/valgus applied forces leading to articular depression, malalignment and an increased risk of post-traumatic osteoarthritis (Manidakis et al., 2010).

Defined lateral tibial plateau fractures type II as cleavage combined with depression: a lateral wedge is split in addition varying portions of the remaining lateral tibial plateau and articular surface are comminuted and depressed downwards into the metaphysis, while type III as pure central depression: the articular surface of the lateral plateau is depressed and driven into the lateral tibial condyle. There is no lateral wedge and the lateral cortex is intact (Papagelopoulos et al., 2010).

Depressed tibial plateau fractures remain technically demanding for orthopaedic trauma surgeons. The main challenges consist of achieving anatomic joint reduction in conjunction with stable 
fracture fixation, to allow early range of motion of the knee, with the aim of achieving good functional outcomes (Luo et al., 2010). Further limitations include the risk of a residual intra-articular stepoff after insufficient articular reduction6 and the adequacy of bone grafting options to fill the metaphyseal void after fracture reduction with conventional bone tamps (Mauffrey et al., 2012a \& b). Anatomical reconstruction of tibial plateau fractures is necessary to prevent pain, axial malalignment, knee join instability and posttraumatic arthritis (Suero et al., 2010).

Considering the articular reduction of tibial plateau fractures, much variability remains as to the accepted amount of residual step-off, with some authers recommending $3-4 \mathrm{~mm}$. This is most likely the result of imperfect reduction tools, as anatomic reduction is always preferred. Though posttraumatic arthritis at the knee is correlated more with overall joint alignment and stability, restoring the native anatomy is always the goal (Broome et al., 2012).

In the surgical treatment of depression fractures (Schatzker II-III) of the lateral tibial plateau (which constitute more than $50 \%$ of all tibial plateau fractures) the goal is reduction of the articular surface and stable fixation (Broome et al., 2012). Access to the subchondral bone is gained through a cortical window or other fenestration in the metaphyseal bone. A tamp or elevator is then inserted and used to elevate the depression en bloc. The subchondral defect in the metaphysis is usually grafted with bone from the iliac crest to support the elevated articular surface or by elevation of this depression by subchondral screws $3.5-6.5 \mathrm{~mm}$.
Disadvantages are pain symptoms (Goulet et al., 2010), and other donor site complications (Arrington et al., 2010), as well as resorption of the graft with subsequent loss of reduction.

At present there is no consensus as to the weight-bearing regime that should be followed after fixation of fractures of the tibial plateau. Recommendations vary from non-weight-bearing for 12 to 16 weeks, non-weight bearing for six to eight weeks, non-weight bearing prescribed on an individual basis or immediate partial weight-bearing for all patients (Brantigan and Voshell, 2010).

Drake et al. (2018) suggested the use of the subchondral raft screws with plate fixation technique using small fragment screws $3.5-6.5 \mathrm{~mm}$ without bone grafting for the treatment of split depressed fractures of tibial plateau. Therefore, avoiding morbidity associated with bone grafting without compromising the fracture stability.

The purpose of this study was to evaluate the clinical, radiographic and functional results in a cohort of patients who sustained open reduction and internal fixation by rafting screws $3.5-6.5 \mathrm{~mm}$ cortical screws

\section{PATIENTS AND METHODS}

This was a prospective randomized controlled study that included 30 patients with lateral tibial plateau fracture Schatzker type II or type III subjected to open reduction and internal fixation with rafting cortical screws $3.5-6.5 \mathrm{~mm}$ and those by bone grafts.

Inclusion Criteria: All patients with fracture lateral depressed tibial plateau 
included: Fractures Schatzker type II or III. Sex: both sexes. Age: males (18-60), females (18-60). Closed fractures.

Exclusion Criteria: Fractures Schatzker type I, IV, V and VI. Open fractures. Fractures with vascular injury. Concomitant injuries to either lower limb that would interfere with rehabilitation of the tibial plateau fracture.

All patients underwent preoperative assessment that included history, physical examination and radiological examination (X-ray and CT). Staging of the fracture based on Schatzker classification system. The amount of depression measured in millimetres through the coronal cuts of CT. Preoperative CT will be used also to predict the volume of the defect left after elevation of the depression. The volume of the defect tried to be measured intraoperative. All the patients underwent postoperative X-ray and CT. An integral part of the work was to evaluate and analyze the radiological outcome and post-operative complications.

Intraoperative Evaluation: Blood loss and transfusion, operative time, radiation exposure, and wound incision.

Postoperative Evaluation: Blood loss and transfusion, complications, time to union, Rasmussen score, and Knee Society Score (KSS).

Postoperative Follow Up: After one week follow up wound condition was noticed. After two weeks follow up incision stitches were removed. Every 2 weeks, the patient was followed up for the first 8 weeks every 2 months for the next
4 months, then after 12 months. Follow up $\mathrm{X}$-ray was done every month for the first 2 months, every 2 months for the next 4 months, then after 12 months

Rasmussen radiological scoring system was used to assess the clinical outcome in the form of the radiological outcomes that determined by Modified Rasmussen Assessment criteria. Scores were graded as Excellent (28-30), Good (24-27), Fair (20-23), Poor $(<20)$.

Knee Society Score (KSS) was used to assess the clinical outcome in the form of the degree of pain, flexion contracture, total range of motion, alignment and stability. The grading for (KSS) score 80100 was excellent, score 70-79 was good, score 60-69 was fair and score below 60 was poor.

\section{Statistical analysis:}

Recorded data were analyzed using the statistical package for the social sciences software (SPSS, Inc., Chicago, Illinois, USA) version 20.0/2011 for windows. Quantitative data were expressed as mean \pm standard deviation (SD). Qualitative data were expressed as frequency and percentage. Mann-Whitney U test was used when comparing between related samples. Chi2 was used to compare the qualitative data the confidence interval was set to $95 \%$ and the margin of error accepted was set to $5 \%$. So, the p-value was considered significant at $<0.05$. 


\section{RESULTS}

A total number of 30 cases were included in this study, 15 cases of them represented the group (A) and 15 cases represented the group (B). The demographic data showed sex distribution as 22 males \& 8 females with closed lateral tibial plateau fractures (18 type II \& 12 type III). The mean age is 35.73 years for the group A, and 35.66 years for group B. The mechanism of injury for all patients was as follow: sixteen fractures were the result of road traffic accidents (RTA), eight resulted from a fall from height, and six fractures were caused by twisting trauma. According to data collected; there was no significant relation between patient age or gender and the type of fracture.

The average hospital stay was 7.6 days (range: 4-12 days) for both groups with no significant difference between both groups. All the patients have closed fracture with no concomitant or associated injuries. Surgery was done after an average 4.66 days (range: 1-10 days) of admission. The detailed demographic data is illustrated. Moreover, Using knee society score for outcome, results of both groups after 1 year postoperatively were collected and summarized in Table (1).

Table (1): The demographic data, Clinical score

\begin{tabular}{|c|c|c|c|c|}
\hline \multicolumn{2}{|c|}{\begin{tabular}{|ll} 
Parameters & Groups \\
\end{tabular}} & \multirow{2}{*}{$\begin{array}{c}\begin{array}{c}\text { Rafting screws (A) } \\
\text { No.=15 }\end{array} \\
35.73 \pm 4.06\end{array}$} & \multirow{2}{*}{$\begin{array}{c}\begin{array}{c}\text { With graft (B) } \\
\text { No.=15 }\end{array} \\
35.66 \pm 4.45\end{array}$} & \multirow{2}{*}{$\frac{p \text {-value }}{>0.05}$} \\
\hline Age & Mean & & & \\
\hline \multirow{2}{*}{ Sex } & Male & $11(73.33)$ & $11(73.33)$ & \multirow{2}{*}{$>0.05$} \\
\hline & Female & $4(26.77)$ & $4(26.77)$ & \\
\hline \multirow{2}{*}{ pathology } & II & $9(60)$ & $9(60)$ & \multirow{2}{*}{$>0.05$} \\
\hline & III & $6(40)$ & $6(40)$ & \\
\hline \multicolumn{2}{|c|}{ Hospital stay (day) } & $7.6 \pm 0.78$ & $7.53 \pm 0.64$ & $>0.05$ \\
\hline \multicolumn{2}{|c|}{ period to have surgery (day) } & $4.67 \pm 0.36$ & $4.67 \pm 0.48$ & $>0.05$ \\
\hline \multirow{2}{*}{ Co-morbidities } & $\mathrm{DM}$ & $4(26.77)$ & $>0.05$ & \multirow{2}{*}{1.0} \\
\hline & HTN & $3(20)$ & $>0.05$ & \\
\hline \multicolumn{2}{|c|}{ Smoking } & $7(46.67)$ & $5(33.33)$ & $>0.05$ \\
\hline \multirow{3}{*}{ Mode of trauma } & RTA & $9(60)$ & $>0.05$ & \multirow{3}{*}{$>0.05$} \\
\hline & $\begin{array}{l}\text { Fall from } \\
\text { height }\end{array}$ & $3(20)$ & $>0.05$ & \\
\hline & $\begin{array}{l}\text { Twisting } \\
\text { trauma }\end{array}$ & $3(20)$ & $>0.05$ & \\
\hline \multirow{2}{*}{ Affected side } & RT & $8(54.33)$ & $>0.05$ & \multirow{2}{*}{1.0} \\
\hline & LT & $7(46.67)$ & $>0.05$ & \\
\hline \multicolumn{2}{|c|}{ Discharge day } & $5.13 \pm 0.32$ & $5.2 \pm 0.21$ & $>0.05$ \\
\hline \multicolumn{2}{|c|}{ Period of follow up (months) } & $6.73 \pm 1.26$ & $7.13 \pm 1.54$ & $>0.05$ \\
\hline Total flexion range & Mean \pm SD & $122.67 \pm 20.63$ & $123.2 \pm 19.52$ & $>0.05$ \\
\hline \multirow{2}{*}{ Flexion contracture } & No & $14(93.33 \%)$ & $14(93.33 \%)$ & \multirow{2}{*}{$>0.05$} \\
\hline & $1-5^{0}$ & $1(6.77 \%)$ & $1(6.77 \%)$ & \\
\hline \multirow{2}{*}{ Extension lag } & No & $15(100 \%)$ & $15(100 \%)$ & \multirow{2}{*}{$>0.05$} \\
\hline & $1-5^{0}$ & 0 & 0 & \\
\hline Sum & Mean \pm SD & $92.27 \pm 19.50$ & $92.87 \pm 21.70$ & $>0.05$ \\
\hline
\end{tabular}


Assessment of postoperative pain using VAS Score in the first day postoperative revealed an average less pain in group A (mean; 49.73) than group B (mean; 58.93) $\mathrm{P}$-value $(<0.05)$. Pain was in both the fracture site and the graft site equally in group B.

In group A patients drew pain as severe in 1 cases $(6.7 \%)$, moderate in 8 cases $(53.3 \%)$, while mild in 5 cases $(33.3 \%)$. While in group B it was severe in 2 cases $(13.3 \%)$, moderate in 12 cases $(80 \%)$, and mild in 1 case $(6.7 \%)$. In the second postoperative day average of VAS continued to be greater in the group B (mean; 40.93) than in group $\mathrm{A}$ (mean; 39.47), P-value (0.01). Pain was in both the fracture site and the graft site equally in group B.
In group A patients drew pain as moderate in 3 cases (20\%), and mild in 12 cases $(80 \%)$. While in group B it was moderate in 12 cases ( $80 \%$ ), and mild in 3 cases $(20 \%)$. After 2 weeks of surgery average of VAS was slightly greater in group B (mean; $31.93 \mathrm{~mm}$ ) than in group A (mean; 30.93). Pain was mostly in the graft site for the control group.

In group A, patients drew pain as moderate in 1 case $(6.7 \%)$, mild in 13 cases $(86.7 \%)$ and 1 patient did not have pain, while in group B it was moderate in 3 cases $(20 \%)$ and mild in 12 cases $(80 \%)$. After 3 months, postoperatively the average of VAS returns to be greater in the group A (mean: 19.56) than in group B (mean: $8.9 \mathrm{~mm}$ ), $\mathrm{p}$-value $=0.04$. Pain was mostly in the graft site (Table 2).

Table (2): The mean of VAS score at day 1, day 2, day 14 and after 3 months

\begin{tabular}{|c|c|c|c|c|c|}
\hline \multirow{2}{*}{\multicolumn{3}{|c|}{$\begin{array}{ll}\text { VAS Measurement } & \text { Groups }\end{array}$}} & Rafting screws (A) & With graft (B) & \multirow{2}{*}{ P-value } \\
\hline & & & No. $=15$ & No. $=15$ & \\
\hline \multirow{5}{*}{$\begin{array}{c}\text { VAS } \\
\text { score at } \\
\text { day } 1\end{array}$} & \multirow{2}{*}{ Score } & Mean \pm SD & $49.73 \pm 11.81$ & $58.93 \pm 16.80$ & \multirow[b]{2}{*}{$>0.05$} \\
\hline & & Range & $30-75$ & $40-90$ & \\
\hline & \multirow{3}{*}{ Severity } & Mild & $5(33.3 \%)$ & $1(6.7 \%)$ & \multirow{3}{*}{$>0.05$} \\
\hline & & Moderate & $8(53.3 \%)$ & $12(80.0 \%)$ & \\
\hline & & Sever & $1(6.7 \%)$ & $2(13.3 \%)$ & \\
\hline \multirow{4}{*}{$\begin{array}{c}\text { VAS } \\
\text { score at } \\
\text { day } 1\end{array}$} & \multirow{2}{*}{ Score } & Mean \pm SD & $39.47 \pm 9.37$ & $40.93 \pm 13.50$ & \multirow[b]{2}{*}{$>0.05$} \\
\hline & & Range & $20-55$ & $30-70$ & \\
\hline & \multirow{2}{*}{ Severity } & Mild & $12(80.0 \%)$ & $3(20.0 \%)$ & \multirow{2}{*}{0.001} \\
\hline & & Moderate & $3(20.0 \%)$ & $12(80.0 \%)$ & \\
\hline \multirow{5}{*}{$\begin{array}{c}\text { VAS } \\
\text { score at } \\
\text { day } 14\end{array}$} & \multirow{2}{*}{ Score } & Mean \pm SD & $30.50 \pm 10.70$ & $37.00 \pm 9.19$ & \multirow{2}{*}{$>0.05$} \\
\hline & & Range & $0-50$ & $20-50$ & \\
\hline & \multirow{3}{*}{ Severity } & Mild & $13(86.7 \%)$ & $12(80.0 \%)$ & \multirow{3}{*}{$>0.05$} \\
\hline & & Moderate & $1(6.7 \%)$ & $3(20.0 \%)$ & \\
\hline & & No pain & $1(6.7 \%)$ & $0(0.0 \%)$ & \\
\hline \multirow{4}{*}{$\begin{array}{c}\text { VAS } \\
\text { score } \\
\text { after } 3 \\
\text { months }\end{array}$} & \multirow{2}{*}{ Score } & Mean \pm SD & $8.90 \pm 10.73$ & $19.56 \pm 13.80$ & \multirow{2}{*}{0.04} \\
\hline & & Range & $0-30$ & $0-40$ & \\
\hline & \multirow{2}{*}{ Severity } & Mild & $7(46.7 \%)$ & $12(80.0 \%)$ & \multirow{2}{*}{$>0.05$} \\
\hline & & No pain & $8(53.3 \%)$ & $3(20.0 \%)$ & \\
\hline
\end{tabular}

In group $\mathrm{A}$, patients drew pain was mild in 7 cases $(46.7 \%)$ while 8 cases $(53.3 \%)$ had no pain. In group B, it was mild in 12 cases $(80 \%)$, and there was no pain in 3 cases $(20 \%)$. The mean radiological Rasmussen score was 15.46 (range: 14-18) in the group A, while it was 15.33 (range: 14-18) in group B (Table 3). 
Table (3): The mean of radiological score

\begin{tabular}{|c|c|c|c|c|}
\hline \multirow{2}{*}{\multicolumn{2}{|c|}{\begin{tabular}{|ll} 
Radiological score & Groups \\
\end{tabular}}} & Rafting screws A & With graft $B$ & \multirow{2}{*}{ P-value } \\
\hline & & No. $=15$ & No. $=15$ & \\
\hline \multirow{2}{*}{ Depression } & Mean \pm SD & $5.07 \pm 0.76$ & $5.60 \pm 0.84$ & \multirow{2}{*}{$>0.05$} \\
\hline & Range & $4-6$ & $4-6$ & \\
\hline \multirow{2}{*}{ Condylar widening } & Mean \pm SD & $5.33 \pm 0.98$ & $5.40 \pm 0.97$ & \multirow{2}{*}{$>0.05$} \\
\hline & Range & $4-6$ & $4-6$ & \\
\hline \multirow{2}{*}{ Angulation } & Mean \pm SD & $6.00 \pm 0.00$ & $6.00 \pm 0.00$ & \multirow{2}{*}{ NA } \\
\hline & Range & $6-6$ & $6-6$ & \\
\hline \multirow{2}{*}{ Sum } & Mean \pm SD & $15.47 \pm 1.36$ & $15.33 \pm 1.41$ & \multirow{2}{*}{$>0.05$} \\
\hline & Range & $14-18$ & $14-18$ & \\
\hline
\end{tabular}

Residual articular depression was slightly less in group A than group B, but residual condylar widening was slightly more in the group B. There was no residual angulation in all cases of both groups. There was no significant difference in the radiological results in relation to the type of fracture in both groups. The mean time to achieve union was 14.86 weeks (range: 11-19 weeks) in group A and 14.93 weeks (range: 9-17 weeks) in group B. The mean of the operative time was 95.93 minutes in group A (range; 60-180 mins) and 101.13 minutes (range; 90-180 mins) $\mathrm{P}$-value $=$ 0.00 . The average amount of blood loss during surgery and postoperatively was greater in group B than group A, about $(206.67 \mathrm{ml})$ in the study group, and $(236.67 \mathrm{ml})$ in the control group (Table 4).

Table (4): The mean of operative time, the mean of amount of blood loss

\begin{tabular}{|c|c|c|c|c|}
\hline \multirow{2}{*}{\multicolumn{2}{|c|}{$\begin{array}{ll}\text { Parameters } & \text { Groups } \\
\end{array}$}} & Rafting screws A & With graft $B$ & \multirow{2}{*}{ P-value } \\
\hline & & No.=15 & No. $=15$ & \\
\hline \multirow{2}{*}{$\begin{array}{l}\text { Operative } \\
\text { time (min) }\end{array}$} & Mean \pm SD & $95.93 \pm 23.45$ & $101.13 \pm 23.19$ & \multirow{2}{*}{$>0.05$} \\
\hline & Range & $60-180$ & $100-180$ & \\
\hline \multirow{2}{*}{ Intraoperative blood loss (cc) } & Mean \pm SD & $100.00 \pm 0.00$ & $113.33 \pm 25.82$ & \multirow{2}{*}{$>0.05$} \\
\hline & Range & $100-100$ & $50-200$ & \\
\hline \multirow{2}{*}{ Postoperative blood loss (cc) } & Mean \pm SD & $106.67 \pm 43.85$ & $123.33 \pm 74.54$ & \multirow{2}{*}{0.00} \\
\hline & Range & $50-200$ & $150-400$ & \\
\hline \multirow{2}{*}{ Sum } & Mean \pm SD & $206.97 \pm 58.26$ & $330.00 \pm 78.88$ & \multirow{2}{*}{0.00} \\
\hline & Range & $50-300$ & $250-450$ & \\
\hline
\end{tabular}

Complication had occurred in five patients in our study, three in group A and two in group B, demonstrated. All of them didn't require aggressive treatment (Table

didn't require aggressive treatment (Table
5).

Table (5): Complications following surgery in both groups

\begin{tabular}{|c|c|c|}
\hline$\left(-2 a^{2}\right.$ & group A (15) & Group B (15) \\
\hline No complications & $13(86.67 \%)$ & $11(73.33 \%)$ \\
\hline Wound infection & $1(6.67 \%)$ & $2(13.33 \%)$ \\
\hline Injury to the lateral cutaneous nerve of the thigh & NO & $2(13.33 \%)$ \\
\hline Knee Stiffness & $1(6.67 \%)$ & NO \\
\hline Total number of complications & $2(13.32 \%)$ & $4(26.67 \%)$ \\
\hline
\end{tabular}


Wound Infection: Infection had occurred in one case of group A and two cases in group B. The infection was superficial and was treated by daily dressing and antibiotics after wound swab, culture and sensitivity had been done. The infection took about 2 to 3 weeks to resolve. There was no need for debridement or any other aggressive procedure.

Knee Stiffness: This occurred in one case of group A due to missed follow up for

\section{DISCUSSION}

In our controlled study, which included 30 patients, we followed up 15 patients with type II and type III fractures that were treated by open reduction and internal fixation without the use of any type of bone graft, but by use of rafting screws to elevate depression, both radiologically and functionally. Also, we compared them to the other group with type II and III fractures treated by the same protocol of treatment by using rafting screws or bone grafting.

The study included 22 males \& 8 females with closed lateral tibial plateau fractures, 18 patients were classified as type II, and 12 patients were as type III fracture.

The average age at operation was 35.67 years with follow up period ranged from (12-18) months with an average of 14 months. Bony union was achieved at a mean of 14.86 (rang, 11-19) weeks in group A and 14.93 (rang, 8-17) weeks in group B.

As regard to radiological outcome, there was no significant difference between both groups. They had nearly equal outcomes, and the functional long period while the joint was splinted. It was treated by aggressive physiotherapy to regain $\mathrm{ROM}$.

Injury to the Lateral Cutaneous nerve of the Thigh: It occurred in two cases in group B. It was neuropraxia in both cases. Neurotonics were prescribed to both patients. Pain resolved after 1 month in one case and after 3 months in the other one.

outcome was also nearly equal, in the group A.

Generally, VAS (Visual analogue score) was minimal in group $\mathrm{A}$ as compared to the group B because of the absence of graft site pain in the group A.

Measurement of operative time and operative blood loss both intra and postoperatively were done. Operative time was also shorter in group A than in group B. Blood loss was minimal in group A as compared to group B (mean $236 \mathrm{~mm}$ ), with no other serious complications.

Molenaars et al. (2015) reviewed the outcome after open reduction and internal fixation of split-depression ( $>5 \mathrm{~mm}$ ) tibial plateau fractures. Periarticular raft construct through a locking plate was used without bone grafting. None had any intra-operative complication, frank infection, osteomyelitis, osteoarthritis, implant failure, breakage, or screw backout. They recommended that fixation using a periarticular raft construct through a locking plate without use of a bone graft or bone substitute for split-depression proximal tibial plateau fractures can be a viable option.

Cross et al., (2013) stated acceptable results without any failure of fixation or 
significant joint depression or articular malalignment in the sagittal or coronal plane or implant loosening. The $\mathrm{x}$-rays at the latest follow up did not show any late joint collapse despite the mode of fixation. Suggested that the addition of 6.5 cancellous lag screws to periarticular plates irrespective of the implants, fracture patterns and the underlying bone quality in the treatment of depressed proximal is a good modality of treatment thus preventing the use of a bone graft or a bone substitute.

Singleton et al. (2017) showed that patients with smaller amounts of residual articular depression at 3.9 years had significantly smaller losses in their knee range of motion. Across all groups, average knee range of motion in the unaffected knee was 0-131 degrees compared with 4-119 degrees in the injured knee. Patients with lesser amounts of residual articular depression also had less disability with significantly better functional and pain scores. The mean VAS score was 7.77 in patients with < $2.5 \mathrm{~mm}$ depression, 6.50 in patients with depression $2.5-5 \mathrm{~mm}$ and 6.56 in patients with depression $>5 \mathrm{~mm}$. Further analysis found that age and gender did not have any significant effect on outcome. There was a trend for worse functional outcome scores and greater losses in knee range of motion with more severe fracture grades.

Kayali et al. (2016) stated that the average time gap between operation and partial weight bearing was around 8.74 weeks ( 8 to 13 weeks). The mean period of radiological union was 12.85 weeks (range 12 to 16 weeks). Average time gap for complete weight bearing was 13.15 weeks. Most of the patients $(60 \%)$ had $120^{\circ}$ or more knee flexion. Average range of motion was $112.8^{\circ}$.

By comparing our results in the study group to the control group or the results of the previous studies, we can find that the results are nearly equal. There was no much difference between using bone graft or not in treating depressed lateral tibial plateau type II and type III with depression $(<1.5 \mathrm{~cm})$ as regard to functional outcome, time of bony union, radiological results and complications. Without using graft, complications of harvesting bone graft are avoided with shorter time of surgery and minimal blood loss. However, the use of graft has the advantage of early range of motion and shorter periods for bone union. Our results are also nearly equal to the results of other studies where small set $3.5 \mathrm{~mm}$ raft construct Were used.

\section{CONCLUSION}

Treating depressed tibial plateau fractures type II and type III with mild or moderate depression $(<1.5 \mathrm{~cm})$ by open reduction and internal fixation using large set buttress plate and screws or screws alone without using bone graft or bone graft substitute represented a viable option. Functional and radiological results without using graft were slightly lesser than when graft was used, but it avoided possible donor site complications of the graft, decreased blood loss and minimized operative time.

\section{REFERENCES}

1. Arrington ED, Smith WJ, Chambers HG, Bucknell AL and Davino NA. (2010): Complications of iliac crest bone graft harvesting. Clin Orthop Relat Res., 329:3009. 
2. Brantigan OC and Voshell AF. (2010): The mechanics of the ligaments and menisci of the knee joint. JBJS, 23(1): 44-66.

3. Broome B, Mauffrey C, Statton J, Voor M and Seligson D. (2012): Inflation osteoplasty: in vitro evaluation of a new technique for reducing depressed intra-articular fractures of the tibial plateau and distal radius. J Orthop Trauma, 13:89-95.

4. Cross WW, Levy BA, Morgan JA, Armitage BM and Cole PA. (2013): Periarticular raft constructs and fracture stability in split-depression tibial plateau fractures. Injury, 44(6): 796-801.

5. Drake RL, Vogl W, Mitchell AWM, Tibbitts R, Richardson $P$ and Horn $A$. (2018): Gray's basic anatomy. 2nd ed. Pbl. Philadelphia: Elsevier/ Churchill Livingstone, Pp. 213-230.

6. Goulet JA, Senunas LE, DeSilva GL and Greenfield ML. (2010): Autogenous iliac crest bone graft. Complications and functional assessment. Clin Orthop Relat Res., 339:7681.

7. Kayali C, Öztürk H, Altay T, Reisoglu A and Agus H. (2016): Arthroscopically assisted percutaneous osteosynthesis of lateral tibial plateau fractures. Canadian journal of Surgery, 51(5): 378-83.

8. Luo CF, Sun $H$, Zhang $B$ and Zeng BF. (2010): Three-column fixation for complex tibial plateau fractures. J Orthop Trauma, 24(11):683-92.
9. Manidakis $\mathbf{N}$, Dosani A, Dimitriou $\mathbf{R}$, Stengel D, Matthews $\mathbf{S}$ and Giannoudis $\mathbf{P}$. (2010): Tibial plateau fractures: functional outcome and incidence of osteoarthritis in 125 cases. Int Orthop., 34(4):565-70.

10. Mauffrey $C$, Madsen $M$ and Bowles RDS (2012a): Using the proximal ulna as a novel site for autogenous bone graft harvesting: surgical technique. Curr Orthop Pract., 23(4):386-9.

11. Mauffrey $C$, Madsen $M$, Bowles $N$ and Seligson D. (2012b): Bone graft harvest site options in orthopaedic trauma: a prospectivein vivo quantification study. Injury, 43(3):323-6.

12. Molenaars RJ, Mellema JJ, Doornberg JN and Kloen P. (2015): Tibial plateau fracture characteristics: computed tomography mapping of lateral, medial, and bicondylar fractures. JBJS., 97(18): 1512-1520.

13. Papagelopoulos PJ, Partsinevelos AA, Themistocleous GS, Mavrogenis AF, Korres DS and Soucacos PN. (2010): Complications after tibial plateau fracture surgery. Injury, 37(6):475-84.

14. Singleton N, Sahakian $V$ and Muir D. (2017): Outcome after tibial plateau fracture: how important is restoration of articular congruity? Journal of Orthopaedic Trauma, 31(3): 158-163.

15. Suero EM, Hüfner T, Stübig T, Krettek C and Citak M. (2010): Use of a virtual 3D software for planning of tibial plateau fracture reconstruction. Injury, 41(6):589-91. 


\section{المسامير الر امثة مقارنة بالرقع العظمية في كسور مسرح الركبة}

\section{المنخفضة}

\section{محمد أحمد عبد الصمد دسوقي, علي الجيوشي، إيهاب الزاهد}

\section{قسم جراحة العظام، كلية الطب ؛ جامعة الأزهر}

Email: m2a.sabawy@gmail.com

خلفية البحث: تؤثر كسور الهضبة الظنبوبية على مفصل الركبة الذي يعتبر من الدفاصل الاساسية والتي

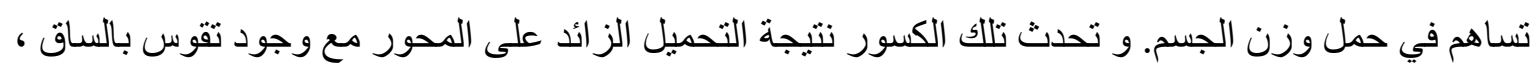
وسوء المحاذاة' وكذلك تتمكن خطورتها بزيادة خطر الإصابة بهشاشة العظام بعد الاصابة. الهدف من البحث: مقارنة المسامير الر امثه بالرقع العظمية في كسور مسرح الركبة المنخفضة. المرضي وطرق البحث: تم تضمين إجمالي عدد 30 حالة في هذه الدراسة، منها 15 حالة تمثل المجمو عة (أ)

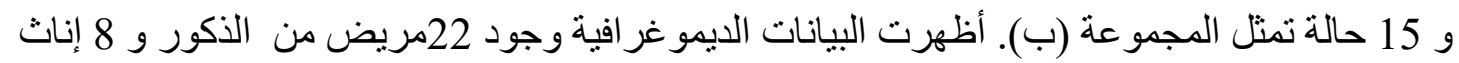

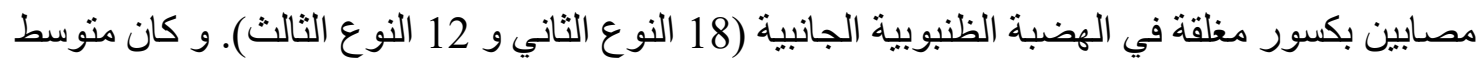

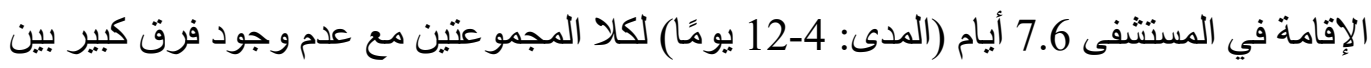

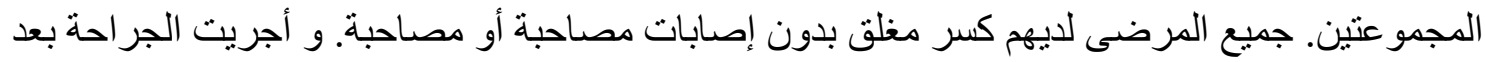
4.66 يومًا في المتوسط (المدى: 1-10 أيام) من القبول.فى الفترة مابين ديسمبر 2019 حتى نوفمبر 2020.

نتائج البحث: فيما يتعلق بنتائج الاشعة السينية، لم يكن هناك فرق كبير بين المجمو عتين. وكانت النتائج

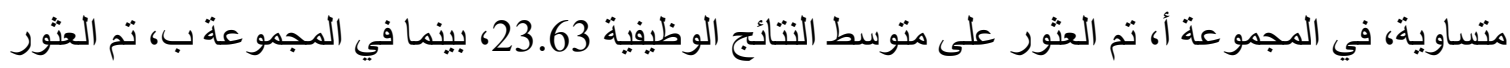

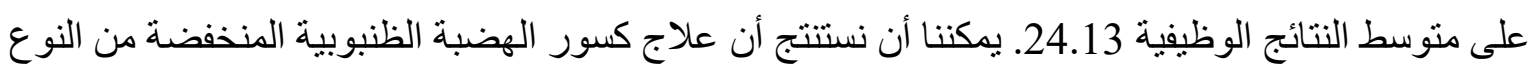
الثاني و النوع الثالث مع انخفاض خفيف أو متوسط (>1.5 سم) عن طريق التخفيض المفتوح و التثبيت الداخلي باستخدام لوحة دعامة كبيرة ومسامير أو مسامير بمفردها دون استخدام ترقيع عظمي يمثل خيار قابل للتطبيق. الاستتتاج: لا يوجد فارق مؤثر بين إستخدام الرقعة العظمية والمسامير الرامثة في كسور مسرح الركبة المنخفضة الكلمات الدالة : المسامير الرامثة الرقع العظمة كسور مسرح الركبة المنخفضة 